Notre Dame Law School

NDLScholarship

1995

\title{
Human Nature and Moral Responsibility in Lawyer-Client Relationships
}

Thomas L. Shaffer

Notre Dame Law School, thomas.I.shaffer.1@nd.edu

Follow this and additional works at: https://scholarship.law.nd.edu/law_faculty_scholarship

Part of the Legal Profession Commons

\section{Recommended Citation}

Thomas L. Shaffer, Human Nature and Moral Responsibility in Lawyer-Client Relationships, 40 Am. J. Juris. 1 (1995).

Available at: https://scholarship.law.nd.edu/law_faculty_scholarship/856

This Article is brought to you for free and open access by the Publications at NDLScholarship. It has been accepted for inclusion in Journal Articles by an authorized administrator of NDLScholarship. For more information, please contactlawdr@nd.edu. 


\title{
HUMAN NATURE AND MORAL RESPONSIBILITY IN LA WYER-CLIENT RELATIONSHIPS*
}

\author{
Thomas L. SHAFFeR**
}

When Solomon became King of Israel, he prayed not for wealth, possessions, or honor, but for wisdom and knowledge (II Chronicles 1:10). I propose here to take advantage of Solomon's story, and to notice that Solomon sought not only for guidance in being a ruler but also "for the power to serve others, [and] for an understanding heart to discharge the duties and responsibilities of his profession." Not only for jurisprudence, but also for ethics.

In his most famous case as a ruler, King Solomon had to decide which of two women was the mother of a baby; he said, "Fetch me a sword. . . . Cut the living child in two." And the real mother of the child said of the false mother, "[L]et her have the baby; whatever you do, do not kill it." Solomon withheld the sword and decided the case in favor of the person shown by his judicial tactics to be the real mother. "When Israel heard of the judgment which the king had given, they all stood in awe of him; for they saw that he had the wisdom of God within him to administer justice' (I Kings 3:2428). That was jurisprudence. It was the exercise of lethal state power.

The Rabbis, pondering the constituents of "the wisdom of God" that were Solomon's ethic, attributed Solomon's professional talents to "observation . . . extraordinary intuition . . . a keen-sighted appeal to the instincts of human nature ... [and] a shrewd insight into the workings of the human heart." The Midrash says the Lord foresaw that this case was to happen, and, because $\mathrm{He}$ did, $\mathrm{He}$ accelerated the operation of Solomon's virtues; He moved Solomon to give judgment immediately; the Rabbis quoted the Book of Ecclesiastes (10:17): "Happy art thou, O Land, when thy king is a free man."

My interest here is ethics-whether observation, intuition, the ability to make appeals to human nature, and insight into the workings of the human heart are useful as guides for legal judgments

* This was the annual Natural Law Forum Lecture, given at the Notre Dame Law School on April 18, 1995.

** Robert and Marion Short Professor of Law, University of Notre Dame; Supervising Attorney, Notre Dame Legal Aid Clinic; member of the Indiana Bar.

1. Pentateuch and Haftorahs (J.H. Hertz ed., 1960) (emphasis added), p. 167.

2. Ibid., p. 168; VIII Midrash Rabbah, Ecclesiastes (3d ed. 1983), p. 277. 
in relationships between lawyers and clients. A modern American lawyer and her client use power as certainly as Solomon used power and, I suppose, are as manifestly subject to indirection in deciding how to use power as the kings of Israel were. In both cases the enterprise is undertaken, as W.H. Auden put it, on "a moral planet tamed by terror."

In our law offices, we lawyers begin as Solomon did with a view of human persons that precedes our being introduced to clients. The question during this prelude is, "Who are those persons who will come to see me?" That question is certainly jurisprudential, but in this context it is also and primarily ethical. ${ }^{3}$ Potential law students imply reflection of this ethical sort when they provide a law-school admissions committee with "personal statements"; more often than not, applicants tell us that they want to be lawyers so that they can help people. This implies that, whoever people are, they are legitimate objects of a lawyer's concern, and that the reason for a lawyer's concern for people is that she wants to be helpful to them.

Justice James Wilson, one of the first justices of the Supreme Court of the United States, perhaps stated the same ideal in "natural law" language, and certainly stated as well his own Calvinist Christian ideal, when he said that, even if the state (the law) is the noblest work of humanity, the human person is "the noblest work of God"infinitely valuable, relentlessly unique, endlessly interesting. ${ }^{4}$ A preacher in my parish church was more specifically theological. He turned the Petrine Confession (Mark 8:29) around in a sermon, and had the disciple ask Jesus, "Who do you say that $I$ am?" The preacher answered for Jesus: "You are mine. You are precious. And you are forever."'s

Our lawyer begins, then, with assumptions about human nature and moral purposes that are present even before lawyer and client sit down together. Because this person she is to see is the noblest work of God, the lawyer has, from her community, a positive moral

3. Sally B. Purvis says ethics is "about the understandings and guidelines and structures for being and doing that are more conducive to good human life." (More than what? More I suppose than what people would be conducting themselves toward if they lacked such understandings, guidelines, and structures.) Sally B. Purvis, The Power of the Cross: Foundations for a Christian Feminist Ethic of Community (1993), p. 16. "Natural law" is, then, as I will work with the notion here, about ethics more than about politics, although it is also about jurisprudence, because I am talking about the use of law in the law office.

4. Chisholm v. Georgia, 2 Dallas 419, 462-463 (1792).

5. Father William B. Simmons, C.S.C., preaching at St. Mary's Church, Niles, Michigan. 
position on who this person is whom she does not yet know-not what her client will be like, but who her client is. It is a prelude in the agenda I propose here. It is the initial moral focus for observation, intuition, the ability to appeal to human nature, and keen insight into the human heart. Not all lawyers have those professional virtues, but the good lawyers do, and I am going to assume they are in place as I look at two consequent situations:

(1) After I have met and talked to my client, I will decide what to think about what my client wants to do and wants me to do as I help him. ${ }^{6}$

(2) Later, in talking with my client, I hope to observe, to appeal, to locate the insight to understand and the perception that will help me first to understand and then, sometimes, to persuade my client.

My question for today arises in both situations: Are perceptions of and appeals to human nature helpful in doing my law-office work? That is the "natural law" issue.

6. The Power of the Cross: Foundations for a Christian Feminist Ethic of Community, contrasts "power as control" (pp. 19-36) with "power as life"-i.e., power rooted not in dominance but in relationship and mutuality (pp. 37-54). That distinction parallels, at least roughly so, my distinction between jurisprudence and ethics. What I try to include with my first question is not however without reference to power as life, because it begins with regard for the client as important and it aims at a relationship of mutuality. I nonetheless allow myself, as part of my own integrity, initial and un-mutual, interior reflection on my initial perception of what my client wants me to help her with; I hope that the exercise, which is probably inevitable, is not corrosive of mutuality.

7. Richard McBrien, Catholicism (1979), pp. 994-98, defines natural law as "the obligation, perceived by reason, to conform to nature" as well as "the obligation, built into nature, to use reason in moral judgment." In its "classical" manifestations, it is in method deductive; it has tended in that manifestation to become authoritarian and even anti-intellectual, he says. In its modern inductive manifestations (pp. 941-42), it has tended, he says, to be subjective, relativistic, and even antinomian. In most manifestations it depends upon or invokes Aristotle. See also the definition of R.J. Henle, S.J., Saint Thomas Aquinas: The Treatise on Law (1993), p. 47. Miriam Galston, "Taking Aristotle Seriously: Republican-Oriented Legal Theology and the Moral Foundation of Deliberative Democracy," $82 \mathrm{Cal}$. L. Rev. (1994), p. 329, incidentally makes two distinctions that are useful for our present purposes: (i) between perceptions of human nature (the principal inquiry I am making) and "Aristotle's concept of an abstract, transcendent human end" (p. 340 n.30) (which, in my view, cannot work for a believer without becoming a theology); and (ii) between the sacrificial (her word) discipline that reflection imposes on perceptions of human nature, and the happy realization one finds in Aristotle (and sometimes in Catholic culture) that "there may be instances where a person's preferences, innate or acquired, coincide with her interests" (p. 349 n.75).

Richard J. Hughes, "Natural Law," in James F. Childress and John Macquarrie (eds.), The Westminster Dictionary of Christian Ethics, at $412-414$ (1986), gives more emphasis than McBrien does to anthropological intuition-to perceptions of 
It may help to put four cases to give these questions context, as the Bible gives context to wise judgment by telling us the story of Solomon and the two mothers. I am, then, talking about a prelude, two situations, one question, and four cases.

(1) Grandmother. My client asks me to see to the adoption of her three-year-old grandchild by my client and her husband, the child's grandparents. The child's father has deserted the child and the mother of the child. The child's mother has enlisted in the Army. She has the promise, from the federal government, of training and employment that will assure her future-whether she stays in the Army or not. But the Army's recruiting officer insists that she surrender custody of her child before she reports for military training. Adoption of the child by my client, the grandmother, which will carry with it termination of the mother's parental rights, is a drastic way to do what the Army wants, but it is the legal result Grandmother asks

human nature. Hughes gives examples from the ancients to Kant and Sartre. In medieval scholasticism, he says, the emphasis was (as in McBrien) more on reason than on perception, with a reliance on teleology, including the revealed ends for which God created human beings. (Cf. Romans 1:18-21.) Hughes notes that modern Roman Catholic moral theology tends to use natural-law argument as a method for talking about "natural" human functions, with reference both to biological processes and to normative description of the human person (maybe, e.g., when it talks about artificial birth control or laboratory techniques for beginning babies). But this attention to physiology has been, he says, "more a matter of moral assessment than of scientific inquiry," that is, more about (deductive) reason than about perception of the natural. When modern Roman Catholic natural-law theory has then turned to public discourse, he says, it runs into "a major difficulty" because "its view of human nature is likely to be at least as controversial as the moral conclusions at which it arrives."

What Hughes notices here is a political use of pastoral instruction developed for use in the confessional. See James M. Gustafson, Protestant and Roman Catholic Ethics, ch. 4-7 (1978). Whether in the confessional or in political argument (about, say, divorce or contraception), that use of human nature is (was) tendentious and even polemical. Nonetheless, it is important, in criticizing it, not to let go of the understanding, as Iris Murdoch puts it, in The Sovereignty of Good (1970), p. 97, that "the ordinary person does not, unless corrupted by philosophy, believe that he creates values by his choices. He thinks that some things really are better than others and that he is capable of getting it wrong." Once that understanding is in place, it is possible, Murdoch goes on, to see that "Human nature ... has certain discoverable attributes, and these should be suitably considered in any discussion of morality" (78). The trick here, with reference to the "functional" use of human nature in Roman Catholic moralism, is to back up a bit and look around and think some more, rather than to turn away from what is seen as natural, as, in my understanding, some Protestant theology does. See note $\mathbf{4 0}$ infra. I would not want to leave perception of nature out of Hebraic ethics, but, as will appear, I also would not want to pretend that it can really work without consulting Scripture and the memory of the church. 
me to get for her. And, she says, the child's mother will agree to adoption.

Grandmother tells me that she wants to help this little boy. She knows how to raise children. She has resources, material and psychological, superior to the resources her daughter has. In addition to those relevant circumstances, Grandmother is the noblest work of God; she belongs to Jesus; she is precious and she is forever. I have already decided all of that. I decided all of that before I even met Grandmother. Is there any reason I cannot, in this situation, say that what she wants me to do, and what her daughter has agreed to do, is a legitimate part of the help I have pledged myself to give to people who come to me for help?

It would seem that there is. A common perception of human nature is that children and mothers belong together, that the resources of the community should be applied to assist mothers to be mothers, not to take their children away from mothers who fail or seem likely to fail. This perception of human nature is in the law: The statutes and judicial opinions that govern this area of practice sometimes speak of "the best interests of the child," but the law's imposition of power in disputes over placement of children (including the unofficial biases of lawyers and judges) has a bias in favor of parents, especially mothers ${ }^{8}$ - so that, often, advertently or in effect, the determinative legal issue is the "fitness" of the parent, rather than the advantages offered by the grandparent. If there came to be a judicial dispute in this case, the determinative legal issue would be the fitness of my client's daughter to be a mother.

If the law did not have that bias, most of the children in the country would be raised by grandparents. Grandparents almost always have more maturity, more wealth, more peace and stability, than parents have. ${ }^{9}$ But perception of human nature tends to the contrary.

8. This places the moral issue, but it will not be much of a legal issue if the mother consents to adoption. My colleague Professor Eric Smithburn, in his twovolume treatise on family law in Indiana, 14 and 15 Indiana Practice (1991) (Supp. 1993), affirms the modern principle that courts awarding child custody are not supposed to prefer mothers over fathers, citing Johnson $v$. Nation, 615 N.E.2d 141 (Ind. App. 1993), at 14 Ibid., pp. 517-18. But it is possible to infer, from appellate case law discussing a mother's recovery from mental illness, a father's abuse of the mother, the time each parent spends with the children, etc., that Indiana trial judges believe in their hearts that children belong with their mothers. See also Andrea Malin, "Mothers Who Won't Disappear," 16 Human Rights Quarterly (1994), p. 187; and Mary Ann Mason, From Father's Property to Children's Rights (1994), pp. 121-29.

9. Professor Richard Stith, in notes made on this essay in November 1994, 
My first situation, wherein I think about what my client wants me to do, leaves me with misgivings. Sooner or later I may have to say to my client: We have a problem.

There are possibilities for moral conversation in the second situation in this case: The law provides devices other than adoption for what my client's daughter has to do to satisfy the Army. My initial (and, as I think, inevitable) thinking in this case, in my first situation, leads me to prefer the mother. My consulting the law (influenced, no doubt, by its own account of human nature) leads me to think that perhaps I ought to find out what Grandmother needs in order to act, temporarily, as the mother of this child, and then to propose those less drastic legal devices to my client. ${ }^{10}$ Perhaps Grandmother will come to see the case as I see it, to satisfy those requirements with a temporary custody device or with a petition for guardianship.

In this case, deliberation in my first situation did not take long. (Solomon did not take long either, but the Rabbis say that was because he had immediate help from the Lord.) The challenging task was not in the first situation; it is in the second. Grandmother, my client, says she wants adoption; she wants to take over permanently. Nobody, until I speak up-not even the child's mother-is saying Grandmother should not take over. My client wants me to seek for her a judicial order that deprives the mother of the child of legal parenthood. If Grandmother is not quickly won over to my initial inclination to seek something less drastic than adoption, how am I to observe, understand, perceive, and appeal to my client, as we talk together, so that she comes to see the case as I see it? ${ }^{11}$ Does perception of human nature offer me any help in that task?

suggests that there is a difference between the claims to children of grandparents and those of "strangers" (welfare authorities perhaps, or maybe people who have attempted adoption in a legally invalid way). He mentions "many traditional cultures" in which grandmothers are the primary persons involved in child care. These reflections lead him to blur the distinction I make here between adoption as a remedy for my grandmother client and other forms of gaining control over children. I take his distinction to rest on a perception of human nature.

10. I say "propose." I am assuming-in line with any prelude-that this operation invites me to invoke professional power. This may even be a temptation, but I think the danger here is often exaggerated: Power in the lawyer-client relationship is usually less dominant on the lawyer's side than much of the literature on the relationship (including my own) might suggest. Power in the usual case is "complex, shifting, frequently conflicted, and negotiated"-much more so in the law office than in the courts. William L.F. Felstiner and Austin Sarat, "Enactments of Power: Negotiating Reality and Responsibility in Lawyer-Client Interactions," 77 Cornell L. Rev. (1992), pp. 1447, 1497.

11. To diminish conventional views of lawyer power over clients, however, is 
One vehicle for a human nature argument would be the law. I noticed that the law does not provide clear moral guidance here, but the law has an inclination. Its inclination is not narrowly legal, that is, it is not determinative in either a preventive-law sense, or a curative-law sense: If I take this client to the judge who has jurisdiction over adoptions, and if I take along a statement of consent from the mother of the child, the judge will not interfere with what my client wants to do. In argument, I might suppose that Grandmother is wrong, and that I cannot obtain the consent from the child's mother, so that there will be a dispute in the adoption, and a judge will have to decide between my client and the child's mother. In that (suppositious) case, curative law, in court, will favor the child's mother.

That argument to Grandmother would be a contrivance-so much so that it would be hard to separate my use of the law's perception of human nature from threat, from bullying, even.

not necessarily to diminish the cultural and professional power men have over women, white people over black people, Anglos over Hispanics, the mentally acute from the mentally "impaired," etc. Martha Minow, Making All the Difference: Inclusion, Exclusion, and American Law (1990), warns jurisprudes of all varieties against the reliance on "reason" that is characteristic of natural-law thinking (particularly in its "classical" manifestation, see note 7 supra): Much of natural law reasoning has as its premise "a basic human nature, found in the abstract individual capable of reason ... [ [which] risks excluding any who do not meet it" (156). This is equally true of modern (even Christian, even Roman Catholic) "human rights" thinking. Minow's argument is that narrow reliance on reason excludes those who are "different," because those who are different may not qualify as reasonable (151). The common academic account of rationality is removed from context and relationship (151-152). People come to be fungible: "All persons are equal because of this fundamental sameness-yet this sameness seems to be the emptiness left when we are each sheared of all that makes us different"' (152). Because abstract sameness excludes from the first those who are not qualified as reasonable, both natural law rationality and human rights rationality tend to be elitist-in terms not only of intellectual acuity but also of wealth. Thus John Rawls' concern for the person who is worst-off "is put only to the particular person who is not the worst off ... [and] not likely to understand the situation of the worst-off" (154). My predecessor in this series, and my teacher, Professor Robert E. Rodes, Jr., is rather more blunt on the point: "Greatness Thrust Upon Them: Class Biases in American Law," 28 Am. J. Juris. (1983), p. 83.

In any event, this bit of my text sounds one-sided and arrogant: "A note for physicians: If you listen carefully to what patients say, they will often tell you not only what is wrong with them but also what is wrong with you." Walker Percy, Love in the Ruins: The Adventures of a Bad Catholic at a Time Near the End of the World (1971), p. 39. I should therefore add that I should have held myself open to being persuaded to Grandmother's way of seeing it; perhaps I am assuming she has not won me over and that $I$ am not inclined, in this case, as lawyers often are, to give my client the benefit of a doubt. If so, it is probably a fault, but I hope it is an instructive fault. 
Here there is no dispute, and if I do a good job there will be no dispute (in the judicial sense). One of the things a law-office lawyer does is to arrange matters so that dispute is unlikely, and so that, if dispute occurs nonetheless, the lawyer's arrangement will result in limiting the suffering that dispute will cause to his client. Adoption will accomplish my client's objectives, and (assuming I obtain the consent of the child's mother, who is anxious to leave town and put on a uniform) nothing in the law prevents adoption. Adoption is the best possible way to put my client in an advantageous positionvirtually impossible for the child's mother to undo, should she later change her mind. If I make the law's inclination a device for moral argument, I should also make it clear to her what I can do for her, with the law, if she wins our argument.

Would it be more useful, in my moral conversation with my client, to consult my client's perception of human nature, then my own, and then our mutual perception of human nature, and in such a moral conversation to conclude, or argue, that children belong with their mothers ${ }^{12}$ (Resorting to human nature here would not include talking about King Solomon, since that story is scriptural, and, the Rabbis say, is an instance of the extraordinary intervention of the Lord. The moral conversation I am wondering about would be about human nature, not about the will of God.) There is a naive strain in natural law thinking which proposes that, if each of us is reasonable and not disabled by self-deception, Grandmother and I will have the same perception about human nature, ${ }^{13}$ as there is a more rigorous strain that tells me the advantage of natural law argument in moral conversation (if it turns out that I have to argue with my client) is that it depends on reason. ${ }^{14}$ Either way, in natural law theory,

12. But not to assume this outcome. As Dr. Baxter Black puts it, "There are no straight lines in nature-only arcs." "Morning Edition," National Public Radio, June 28, 1994 (7:45 a.m. E.D.T.).

13. Jude P. Dougherty, "Thomas on Natural Law: What Judge Thomas Did Not Say," 69 The Modern Schoolman (1992), p. 395, shows how perceptions of human nature depend on culture (i.e., memory, history, custom). He then argues that it is possible for a person who reasons within these sources to arrive not only at (i) an understanding of what is good, but also at (ii) a teleology that is plausible if not adequate. Compare Galston's discussion, supra note 7 , of modern jurisprudes who adopt Aristotle on the first of Dougherty's propositions, but divide over the second.

14. My teacher, the late Professor Anton-Herman Chroust, demonstrated a difference, in ancient natural law thought, between perceptions of human nature that are intuitive and perceptions that are based in reason. The issue he discussed then is which of these modes of perception leads to a morality of the common good or explains a person's being affiliated in family and community. "Natural Law and 
Grandmother is open to being persuaded by an argument that appeals to human nature in a way she may not be open to a story from Scripture or a paragraph from Rerum Novarum. So says what I am calling the naive strain in natural law thinking. But the proof of the pudding is in the eating, and such experience as I have with clients leads me to have my doubts.

(2) Tenant. My second client is an eccentric housekeeper. She lives in leased premises and does not keep her house as neat as the landlord and her neighbors say she should. I will leave to your imagination the way the house looks, from inside and from outside, and will add to the story, for the present, only the additional fact that my client is not following a list of housekeeping standards provided by her landlord-standards that are incorporated into her lease.

Here, again, there is a perception of human nature in the law: People should keep their promises. In the Tenant's case, if I get my own morals from the law, or from the law's perception, I suppose I can announce to my client that she has agreed, in signing the lease, to abide by the landlord's housekeeping rules, and either that the law requires her to do so or that the law in some way says she should.

Here, again, though, there is a difference between the law's perception and how I might use the law to get for my client what she wants. I might conclude that the landlord's rules conflict with what my client wants me to do, and with her own understanding of

\footnotetext{
'According to Nature' in Ancient Philosophy," 23 Am. J. Juris. (1978), p. 73. The comparison implies a source of evaluation, as, I think, does Ann Landers, "If girls wear them, why don't boys have virginity tokens, too?" The South Bend Tribune, Dec. 8, 1994, p. D-8, col. 1, 3-4: "[O]ur son listened while his dad and I explained why we waited until marriage to have sex, and then, he made a pledge that he, too, would wait.... This was done in the privacy of our home with no religious overtones. We made our own rules based on the fact that we are intelligent, civilized human beings." I wondered where these people came from. I confess that I suspected that there is a rabbi or a little Sunday School or "Jesus Loves Me" somewhere in their intelligent, civilized moral reasoning; otherwise, with the scientific information and technology available for safe sex, and with Miss Landers' frequent advice that teen-agers should be told to use birth control because no one can expect them to abstain, why would a teen-ager want to remain a virgin? Compare Calvin Trillin's explanation of the only moral admonition he remembers from his father's talking to him: "You might as well be a mensch." A mensch, Trillin says, is "a person who always does the right thing, in matters large and small; a person who would not only put himself at risk for a friend but also leave a borrowed apartment in better shape than he found it." "Personal History: Messages from My Father," The New Yorker, June 20, 1994, p. 61. Trillin's father's admonition implies religious overtones more clearly than Miss Landers' correspondent's, but my guess is that religion abides in both.
} 
what her dignity is. Then I could work with my client to evade and frustrate the landlord's rules-not to deny that they are rules, but to reason them out of practical effect, which is something lawyers do. If my client is in public housing, for example, I can probably keep her in her house indefinitely by insisting that the housing authority follow procedural grievance steps imposed on it by the federal government. That would be to use the rules-no less than the landlord's resort to the housekeeping standards in the lease would be a use of the rules. Still, if I or my client or both of us take moral guidance from the law, "objectively considered," the moral pointer the law gives is that she should clean up her house. And that moral pointer seems to rest on a perception of human nature.

My own intuition about human nature has more force in the Tenant case than the law does. In the first situation, as I think about what my client wants me to do, I may begin with something like "cleanliness is next to godliness." Justice Wilson, being a Presbyterian as well as a natural law lawyer, may have had difficulty finding filth consistent with being the noblest work of God. Certainly my client's neighbors do. ${ }^{15}$ Even client-oriented lawyers, being relatively neat, relatively clean middle-class people, who in many cases have someone to help them keep their offices and homes clean, are likely to have an interesting time with my messy client. When I thought about it, I cast into my memory and consulted a case we discussed in Professor Rodes' Natural Law course in $1960 .{ }^{16}$ But then I thought about the perception of human nature evident in the stories of Francis of Assisi and Benedict Joseph Labre, both of whom seem to have been indifferent to mess, as well as about some of the bachelor Norwegian farmers Garrison Keillor talks about, and concluded that I could not perceive anything in human nature that would lead me to the principle that cleanliness is next to godliness. ${ }^{17}$ I then come back to the thought

15. Minow, note 11 supra 192 , characterizing the communitarian political theory of Michael Sandel, says, "[T]he experience of political participation provides a means of transforming the self through interaction with others." Robert F. Cochran, Jr. and I suggest a law-office version of the approach in our Lawyers, Clients, and Moral Responsibility (1994); our project suggests, of course, a substantial muting of professional dominance in approaching moral conversations with clients. Both communitarian politics and the attempt at mutuality in professional relationships depend, as Minow puts it, following Carol Gilligan's feminism, on the perception that relationship is prior to identity. Ibid., p. 194.

16. Willkie v. O'Connor, 261 App. Div. 373, 25 N.Y.S.2d 617 (1941); Robert E. Rodes, Jr., The Legal Enterprise (1976), p. 155.

17. Just as it was not, contemporary witnesses to the contrary notwithstanding, "in the natural order of things" for a widow in Victorian England to get only a 
that I have a client who, by her own lights, has things in her house the way she wants them, and who is asking me to help her keep things as they are.

I might conclude that mopping every other week is as consistent with being the noblest work of God as mopping every day is. It might then be a moral mistake to use my professional influence to move my client toward cleanliness. If I were to make such a moral

life interest in her husband's (and often her own) property, or "unnatural" for a young widow to think of remaining single. Anthony Trollope, The Eustace Diamonds I, p. 76; II, p. 109 (Oxford ed. 1983). Irene Herron (Forsyte) hears the latter bit of advice from her repulsive husband's cousin, Jolyon, in John Galsworthy's In Chancery (1960): "You ought not to live alone." There are more benign examples in Trollope's story: Lucy Morris is told to regard the country home of Lady Fawn as "your natural home"-meaning that Lucy had there become a part of the family of which she was not at first a "natural" member, ibid., p. 85. There is a useful difference between the two examples from Trollope: My teacher, Professor Robert E. Rodes, Jr., in "Prospectus for a Symbolist Jurisprudence," 2 Natural Law Forum (1957), pp. 88, 101, as he commented on Professor Edmond Cahn's The Sense of Injustice (1949), might have argued that Lady Fawn's welcome is not exclusively empathic, in that it "can be correlated with other observations of reality into a connected whole" and that it is "responsive to rational persuasion based on other observations of reality" - notably, here, the situation of a penniless and unmarried young woman in that culture. This process of synthesis making is the way we place perceptions of nature, such as the conventions about women that occur in Trollope's novels, into a moral continuum. "Natural-law jurisprudes" might say that this can occur without subjecting the perceptions to a command morality. For example, Michael Frederick Duffy, What Kind of Community? Stanley Hauerwas and James Cone on the Christian Communal Life (doctoral dissertation, University of Virginia, 1993), discusses James Cone's theory of response to suffering, and quotes Cone's A Black Theology of Liberation (1970), pp. 134-145: "The truly Christian response to earthly problems is doing what must be done because it is the human thing to do. The brother's suffering should not be used as a stepping-stone in Christian piety."

The moral conversation I contemplate with Tenant may not be as comfortable as the text suggests. My friend Professor Louis M. Brown, in a letter to me (Sept. 13, 1994): "I suppose a person can have things in her house the way she wants them. But there is a limitation. If the way she wants them is injurious to other parties, then under law and morals the dirty housekeeper ought not have her way. A really dirty house might give off unpleasant odors, attract rodents, even give rise to spontaneous combustion." (Professor Brown, adept as he is in Jewish law, seems here to perceive something communal in human nature.) I base Tenant's case on a composite of several of my clients; the situation I imagine verges toward the offenses Brown describes. Brown argues, as did my colleague, Professor Fernand N. Dutile (after the lecture), that my client and I should talk about them. In any event, the principal complaint my client's critics at first make about her housekeeping does not have to do with rodents, fire, or odor, but is that her behavior does not conform to the landlord's rules. That focus makes a difference, but, of course, it could lead, on examination, to the considerations Brown and Dutile mentionconsiderations that belong, in my view, in the moral conversation my client and I are going to have and that belong as well in the conversation I hope my client will have with her neighbors. See Shaffer and Cochran note 15 supra, ch. 9. 
mistake, I might be saved by carrying my mistaken concern into moral conversation and giving my client an opportunity to persuade me away from my error. ${ }^{18}$ But, given the way I worked out my first question in this case, I do not seem to need to move to the second question. I can provide to my client the help she came to me to get. I will leave her with her almost pristine broom and mop and proceed to defend her from her landlord. ${ }^{19}$ If this is the wrong outcome, it is not an outcome I would avoid by consulting human nature.

(3) Claimant. My third client wants me to seek for him designation and benefits as a disabled person eligible to receive Social Security payments. He has an array of physical difficulties and is of marginal intelligence, but he is at present actually holding down a job. In fact

18. Certainly perception of human nature can be seen, or can be seen to have been, mistaken. Lizzie Eustace tells Lord Fawn, her sometime fiance, that "it was natural" for his lordship to take an interest in the Eustace Diamonds, because they were worth ten thousand pounds. Trollope, note 17 supra, II, 198. Lord Fawn, in rather different human circurnstances, was like Tolstoy's Natasha, who experienced as "simple and natural" her strong attraction to the rake Anatole Kuragin, as she later thought that the kindness of Count Bezuhov (Pierre) was "so natural . . . that there was no merit in his kindness." These are cases, as the Reverend Joseph Emilius tells Lady Eustace, where "nature alone will not always lead us aright." Ibid., pp. 240-41; Leo Tolstoy, War and Peace (Constance Garnett trans., 1976), pp. 619,712 . Years later, when she had settled into being a rural wife and mother, Natasha felt "that the tie that bound her to her husband [not Kuragin] did not rest on those romantic feelings which had attracted him to her, but rested on something else undefined, but as strong as the tie that bound her soul to her body." Ibid., p. 1248. The experience and maturity behind her later conclusion would, in natural law accounts, be attributed, I suppose, to "reason." It may be important to attribute it to some human skill or experience that does exclude people like Natasha, who do not "reason" very well. See Minow, note 11 supra, and Anthony Kronman, "Living in the Law," 54 U. Chi. L. Rev. (1987) (following Aristotle), pp. 835, 858: "The person who shows good judgment in deliberation will thus be marked as much by his affective dispositions as by his intellectual powers, and he will know more than others do because he feels what they cannot."

19. A lawyer runs the risk, in taking such an initial stance with her client, of creating or increasing her client's contempt for the law. Austin Sarat and L.F. Felstiner, "Lawyers and Legal Consciousness: Law Talk in the Divorce Lawyer's Office," 98 Yale L.J. (1989), pp. 1663, 1672, 1684: "It is common for lawyers to mock rules as irrelevant or useless in governing the behavior of legal officials.... In a legal order whose legitimacy rests on the claims of formalism and, to a lesser extent, on those of equity, the law talk of the ... lawyer's office may be partially responsible for the common finding that people who use legal processes tend, no matter how favorable the results of their encounter, to have a less positive view of the law than those with no direct experience." This seems to me a serious risk only when the lawyer does not encourage respect for something more important than the law. But if law is all there is going to be, I suppose a lawyer should remember, as Karl Barth said, that there may be a blessing in it. Richard Ellmann and Charles Feidelson, Jr., "The Knowledge of God and the Service of God," The Modern Tradition: Backgrounds of Modern Literature (1965), p. 942. 
he started a new job (his fifth in two years) just a few days before he came, on his lunch hour, to see about my representation. My client, who in fact works, wants me to argue that he is disabled within the understanding of an administrative system that defines disability as being unable to work.

The law in Claimant's case is in extensive, arcane rules that are as complex as anything in the Internal Revenue Code. These rules operate to restrict access to public funds, and could be said to rest on a sound political and legal perception of human nature that has been turned into two sound natural law principles:

- Human dignity is enhanced by work; and

- Public assistance for the medically needy, a sound governmental objective, is frustrated by allowing people who are able to work to obtain income at public expense.

A lawyer who attends to these perceptions of human nature in the law, in my first situation, finds himself in an astounding position. Almost all people who can qualify for disability payments in the Social Security system literally cannot work. But some of them can. Many more people who are destitute and unable to rescue themselves through work are denied disability benefits. ${ }^{20}$ If the regulations permit my client to be classified as disabled, while they also refuse that classification to thousands of people who are in fact disabled, why should my client not take advantage of a serendipitous fluke in otherwise oppressive legal rules? Why should I not have a lawyer's satisfaction from gaining a point or two on what is in my experience (in other cases) at best stingy and at worst disgusting? There may be a moral inclination in the law, but, as nearly as I can tell, it has been corrupted beyond the point of being interesting for ethics.

Thus the law will not give me pause, but perhaps more intuitive perceptions that human nature is enhanced by work, and that communities are empowered by the communal nature of human beings to insist that people work, ${ }^{21}$ will. If I do take account of such intuitions about human nature and work, about community, and

20. David Hilfiker, Not All of Us Are Saints (1994), teems with examples involving the government's disability system.

21. In a letter to me dated Nov. 28, 1994, my friend and co-author, Professor Robert F. Cochran, Jr. (supra note 15), says: "You might reach your natural law conclusion based on biblical insight-let him who does not work not eat." Some theologians imply an admonition to work from the commandment to observe the Sabbath. See John H. Ricard, S.S.J., "Work: Still at the Center of the Social Question" (Labor Day Statement, United States Catholic Conference, September 1994). But these are not natural law arguments. 
about human nature in poverty, and turn to reflective generalizations that yield moral principles that in turn could be, as we say, "behind" the law, then, I suppose, I am going to need to move to my second question and to talk to my client about his perceptions, my perceptions, and what I can hope will be our perceptions.

(I reject and will not now discuss two possibilities for this case: One possibility would be to say that my client wants me to do something immoral, and I must, without further talk, refuse to do it. The other possibility would be to invoke a law-office version of the adversary ethic and say that it is my job to help my clients get whatever the law will allow them to get. ${ }^{22}$ )

(4) Patriarch. My final client is worth a million dollars. He is secure, opinionated, widowed, and retired. He wants me to draft a will that gives all of his property to two neighbors, a married couple, who look out for his welfare. He wants his will to disinherit his two adult children and their children.

Both law and reflection on law and custom in America might lead me to focus this case on my first situation and then to proceed to talk to my client from a moral agenda that was fixed in my mind as soon as he told me what he wanted-so that my agenda would be more to persuade him than to learn from him. Observations of human nature at work in modern America, along with the views of sensitive moralists and philosophers, suggest the possibility that Patriarch proposes to do something immoral.

Perceptions of human nature in the law would help me do that. The history of the common law on wills, over generations of English and American judges, has used the word "unnatural" for the sort of will Patriarch wants me to draft. ${ }^{23}$ That does not mean such a will would be invalid; liberal democracy and evolving notions about the rights of Englishmen have resolved the law in the direction of allowing such wills even as judges disapprove of them. ${ }^{24}$ Disapproval also issues from reflection on surveys of modern American public opinion that say parents have a moral duty to give their property to their children. ${ }^{25}$ These citizens do not say they think the law should

22. Positions worked out at tedious length in my On Being a Christian and $a$ Lawyer, ch. 1-4 (1980), and in Shaffer and Cochran, supra note 15.

23. W.D. Rollison, The Law of Wills (1939), pp. 686, 689.

24. Ibid., pp. 1-3.

25. Mary Louise Fellows, Rita J. Simon, Teal E. Snapp, and William D. Snapp, "An Empirical Study of the Illinois Statutory Estate Plan," 1976 University of Illinois Law Forum, pp. 717, 736-742; Comment, "A Comparison of Iowans' Dispositive Preferences With Selected Provisions of the Iowa and Uniform Probate 
prohibit wills that disinherit children. They would no doubt resist such legal intrusion as a denial of human rights-as some of the law school casebook editors have done. ${ }^{26}$ But, still, the law in this situation, as well as moral opinion common in the culture, seem to retain an educative force, so that both are entitled to respect. ${ }^{27} \mathrm{I}$ am not able simply to ignore their force on my first question in Patriarch's case.

The problem I see in resting the case in the first situation, rather than in the second, is that it constrains moral conversation with my client, who is the noblest work of God, who belongs to Jesus, and who is precious and forever. That constraint will affect me if I come to my client discouraging such a will, or even refusing to draft it; it will also be affecting, if more subtle, if I come to my client to learn what his morals are on the matter, but have in advance a rather too strong, too fixed opinion on the matter. (I may have moved too far in that direction in Grandmother's case, but in that case there were perhaps better possibilities for a middle ground between what she initially said she wanted and my initial misgivings about doing what she wanted. ${ }^{28}$ ) The moral problem will have been mine, and I will have resolved it, if you like, jurisprudentially, maybe even by adverting to natural law. But I will have failed to observe and to understand, and in that failure will also have failed to accord Patriarch the dignity I decided to give my clients, even before I met them.

Observation and understanding are here logically prior to (if not the sources of) intuition and appeals to human nature. Thus the Rabbis of the Midrash began their reflection on King Solomon, in

Codes," 63 Iowa L. Rev. (1978), p. 1041; John R. Price, "The Transmission of Wealth at Death in A Community Property Jurisdiction," 50 Washington L. Rev. (1975), p. 277; Thomas L. Shaffer, "Fifty Estates in Elkhart County," Res Gestae, (September, 1969), p. 22.

26. E.g., Jesse Dukeminier and Stanley M. Johanson, Wills, Trusts, and Estates (1990), pp. 159-62.

27. Frank S. Alexander, "Validity and Function of Law: The Reformation Doctrine of Usus Legis," 31 Mercer L. Rev. (1980), p. 509.

28. There may be net moral gain from this procedure. My colleague Professor Eileen M. Doran, who has more experience in cases such as Grandmother's than I do, commented on a draft of this paper: "Grandmother will say, of course, that it is not her intent to deprive her daughter of her child, and that the child should always know her mother, etc., etc. Given the choice, Grandmother will come to decide on guardianship, though-at least most of the time.... I think it is in raising the second question with clients [on the way to this middle-ground outcome] that we have forged our most precious relationships-at least in my cases: Clients I have maintained long-term, post-representation relationships with are those to whom I have raised the second question and come to resolutions we both, in the long term, could be happy living with.", 
the dispute over the motherhood of the baby, by imagining his attention to procedural considerations-procedures that put the King in the position to learn from the people he proposed to work with. The Rabbis speak of how the parties are to be seated, and where the judge is to stand. They emphasize that it is important for the judge to repeat the pleas of each of the parties before he begins to deliberate on a decision. ${ }^{29}$ All of this is, I think, in aid of observation and understanding. I suppose, in aid of making a discussable contrast, that that was not the case when I dealt with Grandmother; I decided, in that case, on a moral limit on the help I was willing to give her. I decided that she should not have what she wanted.

In a similar way, I may be tempted, in my conversation with Patriarch, if only to help him think carefully, to say that what he proposes to do is "unnatural." The polls, the thinkers, and the law invite me to do that. But I hope I will not do that. No doubt, in all of these cases, the law has something to say and what it says has a "natural law" basis that might be useful for allusions in a legislature or a court. But, in the law office, I perceive the law's disdain for "unnatural wills" as something to think about after I listen to Patriarch for a while..$^{30}$

How have perceptions of human nature helped determine what we might be tempted to call the natural law of the law office? My conclusion is to doubt that natural law is as helpful as scripture, the memory of the church, ${ }^{31}$ and the community's moral culture. These

29. The Code of Maimonides Bk. 14 (Abraham M. Hershman, trans. 1949).

30. Maybe I should have proceeded that way in dealing with Grandmother, too. I leave that case as I have described it, though, which is also the way I have practiced it.

31. I use "memory of the church," rather than either "theology" or "tradition," in an attempt to suggest more than either of those terms suggest. For one thing, I mean that memory is the product of community-in this case of the community of the faithful, over time. I am indebted to an essay by my colleague Professor Joseph Blenkinsopp, "Memory, Tradition and the Construction of the Past in Ancient Israel"' (unpub. ms. May, 1994). Professor Blenkinsopp there suggests that what Israel in captivity "remembered" was consequent on its communal prayer, on its architecture, and on its legal rules. He says he "remembers" Britain during World War I, before he was born, better than he remembers "his own" Britain in World War II: "My own grandfather gave me, as a child, an emotional and vivid impression of his own memories as a combatant in the Great War of 1914-1918, with the result that the First Ypres, Polygon Wood, Passchendaele, the Somme were (and still are) more real to me than the later war which I survived as a student in a boarding 
religious sources serve legal ethics better than perceptions of human nature do. But I will, in the academic (if not natural) order of things, try to make some observations about the possibilities for appeals to human nature in law office work:

(1) Law works differently here than in courts or lawyer-to-lawyer negotiation for clients. Law is not irrelevant to the enterprise; law operates in the law office to limit, describe, and secure decision. Fact follows law; the direction the lawyer and client decide to take is limited if not often determined by law: A petition to adopt a child is a different thing than an agreement on temporary custody or a petition to establish a guardianship over a child; the difference is legal; clients and lawyers decide to pursue one legal arrangement rather than another - as a matter of fact, but in reference to distinctions in the law. For example, a guardianship is easier to undo than an adoption, and temporary custody or a temporary guardianship will expire by their own terms. Law is not decisive here in the way it is in courts; it is the fact that is decisive; but the fact is what it is because of the legal consequences of the fact. Fact follows law. ${ }^{32}$ In this way there is a difference between law office moral deliberation and moral deliberation in reference to a friend, or between friends, neither of whom is being a lawyer.

Still, moral deliberation in the law office is more like moral deliberation in friendship than deliberation in court-even moral conversation in court. Each of the parties to a law office moral deliberation is concerned to affirm or deny the moral quality of what occurs there. If the parties agree to avoid moral considerations, whether they do so expressly or by implication, they have chosen disdain for moral quality, ${ }^{33}$ but disdain is still moral quality. If the

school in England."

Another example: John the Baptist, quoted in Luke 3:10-14, gives conventional (or expectable rabbinical) moral counsel to those who come to him. "We seem," in reference to such a text, "to be moving along the well-worn paths of normal human conduct, rationally and respectably, behaving (even with advantage to ourselves) with respect to others," Karl Rahner says. But that conventional, communal morality is where "we can experience the coming of the Kingdom of God, if only we want to, and if only we can surrender in hope to the hidden meaning and innermost power of this everyday life of ours." Karl Rahner, The Great Church Year (Albert Raffelt, ed.; Harvey D. Egan, S.J., trans. 1994), pp. 39-40. That is, although the Baptist points to revelation, the memory of Israel is the place from which he points.

32. Louis M. Brown and Thomas L. Shaffer, "Toward a Jurisprudence for the Law Office," $17 \mathrm{Am}$. J. Juris. (1972), p. 125.

33. Thomas L. Shaffer, "Henry Knox and the Moral Theology of Law Firms," 38 Washington and Lee L.Rev. (1981), p. 347, following both Herbert Fingarette and Soren Kierkegaard. 
parties, silently or expressly, together or apart, seek to practice an affirmative morality, they are, silently or expressly, concerned about the substance of what they do to advance the freedom, or the rectitude, or the goodness ${ }^{34}$ of each of them.

(2) My subject is the force (both the validity and the usefulness) of perceptions of human nature in moral deliberation in law office practice. One theoretical agenda item on an occasion such as this is what tag to put on natural law. I want to try to preserve a distinction between the "law" in natural law (which has almost always been the subject of lectures in this series), and human nature as a guide and an argument for the law that is made in the law office. I would not, as to perceptions of human nature, need to call what I see law. When law enters, as it does in the law office dogma that fact follows law, it will be in the form of what "jusnaturalists" call "positive law." It will be a circumstance and a consequence with which the non-legal fact of human nature has to contend. For most purposes, one can regard law ("positive law") here, as I think lawyers routinely do in law office practice, as a tool box, a set of devices and protections lawyers bring to bear on their clients' lives as physicians bring hypodermic needles, X-ray machines, and steroids to bear on the lives of their patients. It would be hard to deny that what I am talking about is natural morality, ${ }^{35}$ but I suspect that some proponents of natural law (in jurisprudence) would say that what I am talking about is not natural law.

(3) I suspect that we find nature, in discussions of this sort, because we have first found a theology. When people, with the

34. Freedom, rectitude, and goodness are possibilities here; they are not the same thing. See a debate on the point between Professor Monroe H. Freedman and me, 36 Cath. U. L. Rev. (1987), p. 331.

35. Natural law moralists need to say-and those who are careful do say-that perception, or intuition, while it may be the first step in arriving at a moral direction without the conscious aid of revelation, is only the first step. Karl Rahner, with a mild jibe at the "conservative" Catholic moralists who invoked natural law as if it were in a code, says "When he appealed to the unchangeable natural law, he too often confused its perpetual character with the time-conditioned form to which he was accustomed." Note 31 supra 11. Which raises the old question of moral relativism, as the alternative to moral truth. Gerald W. Schlabach, in "Augustine's Hermeneutic of Humility: An Alternative to Moral Imperialism and Moral Relativism," $22 \mathrm{~J}$. Rel. Ethics (1994), pp. 299, 325, concludes from a survey of Augustinian literature, however, that, for St. Augustine, the alternatives are (i) ecclesiastical humility, and (ii) institutional violence or what my colleague Professor John Howard Yoder would call Constantinianism. Yoder, The Priestly Kingdom (1984). To the extent that natural law lawyers depend on the state for impositions of lethal force to vindicate their moral arguments, then, "natural law" belongs in the second category; it is the alternative to persuasion and witness. 
interest I have at present, appeal to human nature, they may appeal to it in terms of the revealed destiny of human beings ${ }^{36}$ or the revealed nature of the good life ${ }^{37}$ or a combination of the two. ${ }^{38}$ At

36. Scripture, in Christian reckoning, provides not only a command morality, not only, in the modern phrase, moral "role models," but also an insight into the will of God. Rahner, note 11 supra 14: "Jesus is a creative model for each of our lives. Not in the sense that we are supposed to imitate and copy him, but in the sense that the innermost formative power of a genuinely human life lived from God and oriented toward him has achieved its purest expression in Jesus; and so we can discern in that life how this innermost force, that we reject all too often, actually desires to shape our lives also." Rahner later explains what he means when he uses what has become a trendy word in theological ethics: "[L]ove is the mother of all important knowledge, love and nothing else. May your love abound more and more with knowledge and all discernment. Only where love grows does true gnosis, true knowledge, grow; and God's grace gives one light to understand what a person is before God only in proportion as one loves from the heart." When Christian theologians speak of discernment in this way, though, they are not speaking about "natural" morality, or at least not merely about natural morality. It is in scripture and in the memory of the church that a believing Christian (or in the memory of Israel that a believing Jew) even knows what he means when he uses the word "love." See the argument ("love is not all you need") of Stanley Hauerwas, Vision and Virtue (1974), pp. 93-126.

37. In elaboration of her argument that, "in the moral life the enemy is the fat relentless ego," Iris Murdoch sees the perception of nature as a discipline, an ascetic practice wherein we "give attention to nature in order to clear our minds of selfish care." It is an aid in the "task to come to see the world as it is." Note 7 supra $52,85,91$. Her point suggests the introduction, in modern religious ethics, of consideration of the way that human nature fits into the rest of nature. See Mary Midgley, "The Paradox of Humanism,"' in James M. Gustafson's Theocentric Ethics (Harlan R. Beckley and Charles M. Swezey, eds. 1988), p. 187. Medieval natural law distinguished between natural law and the law of nature, Henle, note 7 supra, but I wonder if what we moderns regard as the growth of the natural sciences will sustain the distinction at anything beyond a semantic level. See, for example, Marie Boas Hall, Robert Boyle on Natural Philosophy (1966), pp. 138-39. Sir Robert (1627-1691), the propounder of "Boyle's Law," took issue with the prejudices of those who adhered to the "pre-eminence of divinity above physiology." Those "prejudices," he said, "will not lie against a person, who has made the investigation of nature somewhat more than a paragon, and having, by a not lazy, nor short enquiry, manifested, how much he loves and can relish the delight it affords. . .." Perhaps he meant to argue that the "naturalist," as much as those who "commend divinity," was on the road to Jerusalem.

38. Karl Barth: "As God holds out his command before us, he tells us about ourselves." Ethics (Geoffrey W. Bromiley, trans. 1981), p. 271. "All that is made exists in and by the blessing of the Lord". What "natural law" means for Barthian ethics is consequent on God's revealing Himself; there are not separate commands to believers as Christians and to believers as people; what natural law means is "understanding God's command, which claims man, as already the command of the Creator and therefore the command of life, as the command which is given with his life," and not "as though we had achieved a natural ethics on which Christian ethics could then be constructed on the upper floors" (pp. 264, 262). This is not quite the argument I make here-that moral argument by believers should be 
least that will be so if they are students and followers of the Catholic Christian tradition and of the "natural law" ethics of Thomas Aquinas. ${ }^{39}$ It is best to admit, and always a bit disingenuous not to admit, at the outset, first, that "natural law" is a theology $y^{40}$ and, second, that the Thomistic project is to describe how people are to

moral argument as believers, should be a witness to what believers believe; but it could be a prelude, because Barth teaches that the believer who argues should understand where she is coming from. My teacher and friend Professor Robert E. Rodes, Jr., not always such a Barthian, in a memo to me of November 1994, says: "Scripture and the memory of the church tell us where to look for human nature. Once we find it, we can point it out." The difficulty I have with the implications of Rodes' observation is this: A believer, carrying out the way of life her faith describes for her, may not be doing enough if all she does is point out what she perceives as the requirement of human nature-even if, thanks to her faith, she is right.

39. My late teacher, Professor Edward F. Barrett, warned, in a lecture in this series, against natural law's being "torn from the whole context of the Summa," so that Aquinas on law (and natural law) might be "criticized and evaluated in isolation." "A Lawyer Looks at Natural Law Jurisprudence," 23 Am. J. Juris. (1978), pp. 1, 4. Alasdair MacIntyre, Three Rival Versions of Moral Inquiry (1990), p. 138, makes a similar argument, and along the way shows how Aquinas, in his discussion of law, used Aristotle theologically. To remove the theology from Thomas's Treatise on Law, Maclntyre says, is to make of it "a fictional treatise on jurisprudence" (p. 135). Professor Stanley Hauerwas, who has for a long time been my teacher, although I have never paid tuition for the privilege, argued in this series that Aquinas' natural law has more to do with virtue than with law. "Natural Law, Tragedy, and Theological Ethics," $20 \mathrm{Am}$. J. Juris. (1975), pp. 1, 9: "If we are to be faithful to Aquinas, natural law is best discussed in terms of how we are able to find a center for our lives amid the many powers, relations, and roles that lay claim to us:" In this perspective, the attempt to perceive human nature is the attempt to perceive how things are, as well as the practice of the virtue of truthfulness, a good habit that holds self-deception at bay. "[N]atural law is not a commitment to finding what all men can agree about, but rather an attempt to show how the commitments incumbent on Christians may enliven the form of the moral life of any man," but that means that "natural law cannot be separated from ecclesiological and sociological assumptions." That is, it is a theology, a theology standing in criticism of the political method used by the church, at various points in its history, to express "a stake in the continuation and perpetuation of historically relative institutions," which, to Hauerwas, "comes close to perverting the nature of the Christian life." Ibid., p. 3, n.5. My colleague, Professor Jean Porter, in "The Connection of the Virtues and the Unity of the Moral Life: Aquinas and Donagan on the Rational Coherence of Morality" (unpub. ms. April 1994), shows how "natural" virtues depend for coherence and direction in a particular human life on "infused" virtues (which are accounted for theologically). Virtue theory in general, according to Gilbert Meilaender, rests on a belief that affects perception. The Theory and Practice of Virtue (1984), p. 93.

40. Cochran's letter, note 21 supra, reminds me that, in some Christian traditions, human nature is described as so seriously sinful that its perceptions would not be reliable sources for morals. "Without the check of revelation," he says, I am not sure that we would know the good. . . . In addition, I do not think that natural law gives us a reason for choosing the good (scripture gives us several)." 
be and to become good, more than it is to validate or criticize the exercises of coercive power that we lawyers call the law. ${ }^{41}$

(4) That being the case, it would be more candid, and probably more effective for a county-seat lawyer to think and speak as a believer. ${ }^{42}$ More effective, in Grandmother's case, to see how she feels about the story of King Solomon. (If Grandmother is a typical modern American, as described by the polls, ${ }^{43}$ she will find forceful moral authority in the First Book of Kings, even if she wants to argue with me about the meaning of the story of Solomon and the two mothers.) More effective, in Tenant's case, to talk about Jewish and Christian life as in service to neighbor rather than in contention with neighbor. ${ }^{44}$ More effective in Claimant's case to invoke reflection

41. Milbank, note 49 infra 381: "[T]heology ... must articulate Christian difference in such a fashion as to make it strange." Milbank began his influential treatise with the observation-relevant here-that "the pathos of modern theology is its false humility." Ibid., p. 1.

42. As he probably is. See my little sermon, "On Religious Legal Ethics," 35 The Catholic Lawyer (1994), p. 393.

43. George Gallup and Jim Castelli, The People's Religion (1989).

44. The Catholic tradition couples "the benign view of human nature" with a communal anthropology, rooted in a revealed perception of human nature, that leads it to insist on the believer's concern for "the well-being of the whole." Michael J. Himes and Kenneth R. Himes, O.F.M., Fullness of Faith: The Public Significance of Theology (1993), p. 17: "A communitarian spirit need not be created," or agreed upon; "it is there." lbid., p. 41. Catholic social theory thus locates and validates "human dispositions toward cooperation and self-giving." Ibid., p. 38. One could buttress such a "natural law" anthropology with scriptural theology, showing how God deals with the people as people (ibid., p. 39), how biblical believers can talk biblically about freedom, equality, participation, and common good (ibid, pp. 3942). This possibility is as realistic for the modern Christian theological ethic that is accused of disregarding common good as it is of the "witnessing" church. The community of the faithful, even when it understands itself as alien in the secular culture, may nonetheless see itself as committed to the welfare of the society in which it finds itself, as in Jeremiah's prophecy to captive Israel (28:4-7): “These are the words of the Lord of Hosts the God of Israel: To all the exiles whom I have carried off from Jerusalem to Babylon: Build houses and live in them; plant gardens and eat their produce. Marry wives and beget sons and daughters. ... Seek the welfare of any city to which I have carried you off, and pray to the Lord for it; on its welfare your welfare will depend." John Howard Yoder, citing Jeremiah as well as Torah commandments on concern for the stranger, the mission of St. Paul, and Rabbi Jochanan ben Zakkai's efforts to find meaning in the destruction of the Second Temple, says of this command to captives: "[T]ake part in everything as citizens, and put up with everything as foreigners. Every foreign land is their home, and every home is a foreign land." Note 35 supra 189. Himes and Himes, supra 148, say that "Catholic theology reminds us it is not only that we love the good in them but that we love the good in them." (When I use "Catholic" in this essay, on my own rather than in what I quote, I mean to include the Christian theology that is evident in Anglican, Lutheran, Orthodox, and Calvinist traditions, each of which has an account of natural law. I try to say "Roman Catholic" when I mean the denomination to which I have come to belong.) 
on the Sabbath commandment-that the Ruler of the Universe there commands rest from work because He first ordains work. More effective in Patriarch's case to notice that the People of God is a people, a people made up of peoples, who are peoples made up of families. $^{45}$

The American Roman Catholic project for reducing moral argument to human nature, ${ }^{46}$ without appeal either to Scripture or to the memory of the church, is not as faithful to the tradition as it seems to propose to be; not as candid about its "deepest values" when it speaks publicly as it should be (believers being called to be witnesses to the Word); ${ }^{47}$ and probably not even as effective as it would be if it paid attention to the polls: The poll takers and the journalists tell us that four-fifths of Americans are church-going believers who, I infer, would be more likely to respond to the Bible and the memory of the church than they would to descriptions of human nature. ${ }^{48}$ 66.

45. James Wm. McClendon, Jr., Systematic Theology: Doctrine (1994), pp. 363-

46. A reference, of course, to the project of the late Father John Courtney Murray, S.J., in which nature appealed to law (whereas, perhaps, in "classical" natural law, law appeals to nature). For present purposes, it is important to notice that Father Murray's method (1) left the Bible out of public discourse, (2) hid traditional Roman Catholic natural-law reasoning, and (3) depended, rather more than Father Murray admitted, on "modernity" (that is, on the Enlightenment). These are the criticisms in Himes and Himes, note 44 supra 13-15; they also discuss David Tracy's "political theology" along somewhat the same lines-notably Tracy's view that the test of a theological position in public discourse is not whether it is rooted in a particular tradition (which is how the speaker knows whether the position is valid or not), but the significance of the position in secular politics. An additional difficulty I have with Tracy's politics-and it is a difficulty in "natural law" argument in lawyer-client discourse as well-is that the speaker tends to lose sight of the stake he has in keeping the tradition true to its theology: He has all sorts of pressure to become politically acceptable when he should seek to be alien, because "a religion cannot be true that is simply private." Ibid., p. 35. See also, as to Murray, the analysis of my colleague Professor Gerard V. Bradley, "Beyond Murray's Articles of Peace and Faith," in John Courtney Murray and the American Civil Conversation (K. Grass and R. Hunt, eds. 1992), p. 181, a critique of Murray's hope that "the religion clauses" in the federal constitution "can be interpreted in such a fashion as to avoid the presuppositions of any particular worldview" (p. 204).

47. Hauerwas thus says: "While it is certainly true that the Christian and the man of goodwill may share much in common, the areas of commonality methodologically [do] not warrant the Christian ethicist to write his ethics as though the convictions of Christians are an afterthought to the moral life. Christian ethics is written for Christians, not for all men." Note 39 supra 6, n. 19, citing Thomas Aquinas' Summa theologiae, II-II, q. 23, a. 7.

48. My colleague, Professor Douglas Kmiec, in a memo to me of Oct. 20, 1994, takes issue with this conclusion in four ways:

(a) Natural law is a means "to open dialogue based on specific religious 
Maybe natural law argument (which I describe in this context as argument based on perceptions of human nature) ignores too much that is too important. Maybe it is just too thin for the law office..$^{49}$

teaching." To argue in public, using candid religious reference, "would very often be perceived as exclusionary or coercive."

(b) Natural law is a way to subject to scrutiny and search the "American proposition" that this "is a democratic republic where morality matters."

(c) It is possible to assert "the natural law structure" as a check on governmental power. To the extent that this structure rests on perceptions of human nature it is radically local and therefore an instance of the traditional Catholic principle of subsidiarity.

(d) The lawyer's invocation of the lawyer's religious morality would either be coercive or would leave the client (who rejects the lawyer's morality) to no morality except that imposed by the law. On this point, though, I would respond, from the polls and from my experience as a law office lawyer, that it is more likely that I will find common moral ground when I invoke religious ethics than when I advance my perceptions of human nature. To the extent that our argument on this point is empirical, perhaps Kmiec and I could agree on trying religious argument first and, when it is rejected as irrelevant (as I think, a rare case), fall back on perceptions of human nature.

49. Thus Professor Barrett was forceful and even vehement in claiming that Thomistic natural law is theology. Note 39 supra 6-7. That has been a common view among my Notre Dame teachers. See, for example, two essays by my late teacher Professor Edward J. Murphy-"Conflicting Ultimates: Jurisprudence as Religious Controversy," 35 Am. J. Juris. (1990), p. 129; and "The Sign of the Cross and Jurisprudence," 69 Notre Dame L. Rev. (1994), p. 1285. See also Douglas W. Kmiec, "The Higher Law Background of the Notre Dame Law School," 37 Am. J. Juris. (1992), p. 213; Douglas W. Kmiec, "America's 'Culture War'-the Sinister Denial of Virtue and the Decline of Natural Law," 3 St. Louis Univ. Pub. L. Rev. (1993), p. 183; Igor Grazin, "Natural Law as a Form of Legal Thinking," 37 Am. J. Juris. (1992), p. 1. This emphasis has a long tradition among Roman Catholics that is, perhaps, more noticeable in theology before the Enlightenment and among modern theologians who resist the Enlightenment. John Milbank, Theology and Social Theory: Beyond Secular Reason (1990), pp. 219-20, for example, describes the theology of Henri de Lubac, who wrote in the 1940's, as showing that "for Augustine, Aquinas and Scotus, one can only specify human nature with reference to its supernatural end. . . [E]verything else is appointed to a relatively fixed natural end, but humanity alone is constituted such that its nature is to transcend itself towards a supernatural fruition."

I am avoiding, against the advice of my friend and teacher Professor Rodes, an attempt to describe the no-combat zone maintained in the Catholic tradition between theology and philosophy. It is helpful, though, even in my evasive way of suggesting how a lawyer might talk about morals with a client in modern America, to notice that the tradition affirms (as the Jewish tradition also affirms), as part of the doctrine that nature disposes to grace, the possibility (as in mysticism) that God speaks directly to the human heart. As Rahner puts it, "[I]n every human being (as a result of the nature of spirit and of the grace of the divine self-communication always offered to everyone) there is something like an anonymous, unthematic, perhaps repressed, basic experience of being oriented to God, which is constitutive of the human person in his concrete makeup. . . " Note 31 supra 363. Of course, the way we know of such mystical experience, even in ourselves, comes from telling and hearing the stories of the mystics-and that, too, is in the memory of the church. It is beyond, or comes to be beyond, the ken of natural morality. 
I am more interested in describing an ethic for believers in the law office than in debunking the teaching of my tradition, that our Creator God speaks through nature as well as through revelation, that human nature has in it, put there by the Creator, an aptitude for grace. The theoretical cleaning up I need to do here, I suppose, is to notice that God as Creator is also the Lord Who reveals Himself, as Creator, in scripture and in the memory of Israel and of the church. It is perhaps enough to notice that a person speaking from formation in Scripture and the memory of Israel and of the church, speaking to a person who has much the same sort of formation, might as well get the theological cards on the table. ${ }^{50}$ The Psalmist says,. "The testimony of the Lord is sure, making wise the simple" (Ps. 19:7), "enlightening the eyes," in the Douay translation.

50. Pope John Paul II's “The Splendor of Truth" (para. 88) (1993), p. 134: "The attempt to set freedom in opposition to truth, and indeed to separate them radically, is the consequence, manifestation and consummation of another more serious and destructive dichotomy, that which separates faith from morality." My friend Professor Hauerwas is more blunt: "It is not even clear that we Christians know what the human species is or what status it may have, since we have surer knowledge that we are creatures than that we are human." "No Enemy, No Christianity: Preaching Between 'Worlds"' (unpub. ms., Jan. 1995).

This is in critical part a matter of Christian witness, beyond good example to conscious evangelization. Father Avery Dulles, S.J., thus rejects both (i) "baroque and romantic" adherence to medieval Catholic culture, and (ii) the embracing of "indiscriminate pluralism on the theory that all cultures are good and that Christian faith can coexist with any of them," in favor of (iii) "critical dialogue with contemporary cultures . . . opposing what is faulty, and attempting to supply what is lacking in them. . . Taking Christian revelation or the gospel as a norm, the Church" should, he says, "attempt through dialogue to shape a culture that is more favorable to Christian faith and practice." Its cooperation with political efforts by other religious groups would have, then, as he says, to be "selective," lest the faithful lose heart: "Before all else, the [Catholic] Church should strive to give its own members a sense of their communal identity as members of the Body of Christ. . . ." He was understood in this (originally oral) essay to say that the history of American Catholicism has been a history in which "the world is setting the agenda for the Church and not the other way around." "The Gospel and Culture: Narrowing the Gap," Woodstock Report (March 1994), pp. 3-5, 10.

The trendy fascination with "postmodernism" (which I take to mean "after we have got shut of the Enlightenment") may provide an opening to religious witness in professional settings that is not provided by rationality in its "modern" forms. James W. McClendon, note 45 supra 455 (1994), suggests "a conceptual shift from a strictly modern understanding in which all knowledge is supposed to rest upon some universally available foundations, to an understanding some have labeled postmodern .... in which claims to knowledge are less breathtaking or absolute, but are more integrally tied to the actual tasks at hand." Such as feeding the hungry, healing the sick, and preferring the poor. As to which, see Anthony V. Alfieri, "Practicing Community," a review of Gerald P. Lopez, Rebellious Lawyering: One Chicano's Vision of Progressive Law Practice (1992), 107 Harv. L. Rev. (1994), p. 1747. 
Wisdom for the simple and enlightenment for the eyes-even for the eyes of lawyers and their clients, downtown, on an ordinary Wednesday afternoon. ${ }^{s 1}$

And, if that is so, one wonders why we lawyers do not seek to demonstrate such theological wisdom more often than, in my experience and observation, we do. That question has often been addressed in the series of lectures of which this one has the honor to be part. And the answer has always been the same: Our deepest conviction about people and what people should do-including lawyers and their clients in law offices-has been driven underground. What remains above ground is secular culture..$^{52}$ The personal has been defined as private, and the private has been set aside. If I depart from the lessons of my valued predecessors in this series, it is to add to that consistent observation the argument that our faith has been driven underground by Jews and Christians. Maybe one of the ways we did that was to talk too much about natural law. ${ }^{53}$

51. Who no doubt needs to remember that God "only comes to those who in patience love ... the provisional." Rahner, note 31 supra 33.

52. In A Small Town in Germany (1968), p. 362, John LeCarre's Bradfield, a British foreign service bureaucrat, and a cynic who (as he thinks) pursues order for its own sake, says that a missing embassy employee who has stolen state secrets "has offended. ... Not as much against myself as you might suppose. But against the order that results from chaos; against the built-in moderation of an aimless society." That is just about all that is left above ground.

53. I am grateful for the assistance of Louis M. Brown, Nicholas Chase, Robert F. Cochran, Jr., Eileen M. Doran, Barbara Gasperetti, Linda Harrington, Dwight King, Douglas Kmiec, Charles E. Rice, Robert E. Rodes, Jr., Nancy J. Shaffer, Richard Stith, Louise Vuono, and John Howard Yoder. 
